\title{
Plant Micro-Reserves in the Valencian Region ( $E$ of Spain): are we achieving the expected results? Passive conservation of relevant vascu- lar plant species
}

\begin{abstract}
Fos, S., Laguna, E. \& Jiménez, J.: Plant Micro-Reserves in the Valencian Region (E of Spain): are we achieving the expected results? Passive conservation of relevant vascular plant species. — Fl. Medit. 24: 153-162. 2014. - ISSN: 1120-4052 printed, 2240-4538 online.

The Valencian Plant Micro-reserves network comprises 298 protected sites, and considerable experience has been progressively accumulated during 15 years of continued management. However, an evaluation of its effectiveness as a tool to protect wild rare, endemic or endangered plants has not yet been made. As part of a larger evaluation effort, this paper assesses the effectiveness of the Valencian PMR network to incorporate the most relevant plants species targeted for conservation in the Valencian region. The results show that $77 \%$ of endemic, about $50 \%$ of rare and $57 \%$ of threatened species are represented in the PMR network. However, a comparison of these results is not possible today due to the lack of good analysis of networks of small protected sites focused on plant protection.
\end{abstract}

Key words: threatened plants, endemic plants, in situ conservation.

\section{Introduction}

Plant Micro-Reserves (hereafter PMRs) are protected areas designated for in situ plant conservation, that were developed as a pioneer project in the Valencian region (formally named Valencian Community), East of Spain. The Valencian model consists of a network of small sites — up to 20 ha - with a high degree of naturalness, legally protected to ensure the conservation of rare, endemic or threatened plant species. The main legal and technical issues on the Valencian PMRs have been summarized by Laguna \& al. (2011, 2013). Valencian PMRs were established by Decree 218/1994 (Anon. 1994) and were conceived as a network of sites devoted to the maintenance of selected populations of Valencian and Iberian endemic plant species, regardless of their degree of threat (Laguna \& al. 2004; Serra \& al. 2004).

Since the declaration of the first PMR, back in 1998, the Valencian network has gradually increased to form a network of 298 sites as of late 2013, largely scattered through the three Valencian provinces (Castellón, Valencia and Alicante; Fig. 1). Altogether, the net- 


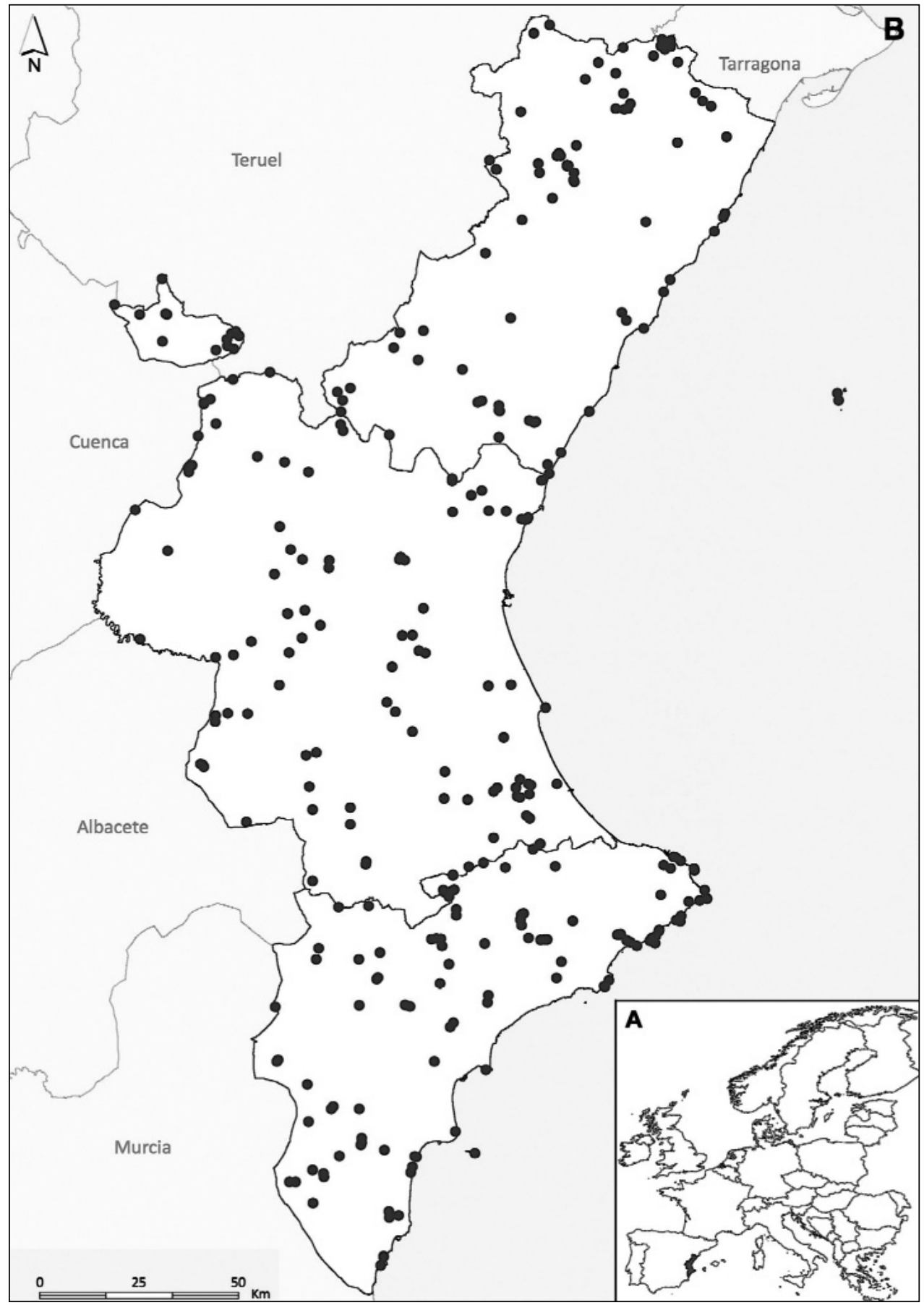

Fig. 1. A, Location of the Valencian Region within Europe. B, Distribution of the Plant MicroReserves network of the Valencian Community, updated to 2013. 
work affords protection to 2152.4 ha (Fig. 2), a surface that accounts for less than $0.1 \%$ of the Valencian territory (2330500 ha). Despite the small surface covered, the Valencian PMR network contains populations of 1.711 native vascular plants up to subspecies level (Servicio de Vida Silvestre 2013), out of 2894 for the whole Valencian region (Mateo \& Crespo 2009). This means that less than $0.1 \%$ of the Valencian territory holds a large proportion $(59.1 \%)$ of its native vascular flora.

Although originally the main goal of PMRs was the protection of the endemic Spanish vascular plants present in the Valencian Community: 399 taxa, of which 70 are strictly endemics to this territory (Servicio de Vida Silvestre op. cit.), following the Decree 70/2009 (Anon. 2009), by which the Valencian Catalogue of Threatened Plants and other categories of plant protection were created, PMRs were re-directed towards the protection of the most endangered species at regional level (Laguna \& al. 2011). The annexes in this Decree include 3 protection levels ranging from strictly to moderately protected species: 'Catalogued Species', 'Non-catalogued Protected Species' and 'Guarded species'. The first group comprises the species included in the Valencian Catalogue of Threatened Plants, within which 2 sub-categories are found: 'Imperiled of Extinction' (42 taxa, hereafter IE) and 'Vulnerable' (83 taxa, VU); these legal categories have no correspondence with the IUCN Red List Categories, despite the fact they sometimes are homonymous (i.e Vulnerable). The remaining protected species are assigned to either of the two minor categories listed above: Protected but non-Catalogued (109 taxa, hereafter PNC) and Guarded species (164 taxa, G). PNC and G species are not as strictly protected as catalogued taxa. For instance, as a result of impact environmental assessment for public works their populations can be affected. In the case of G species, the aerial parts can be harvested in small

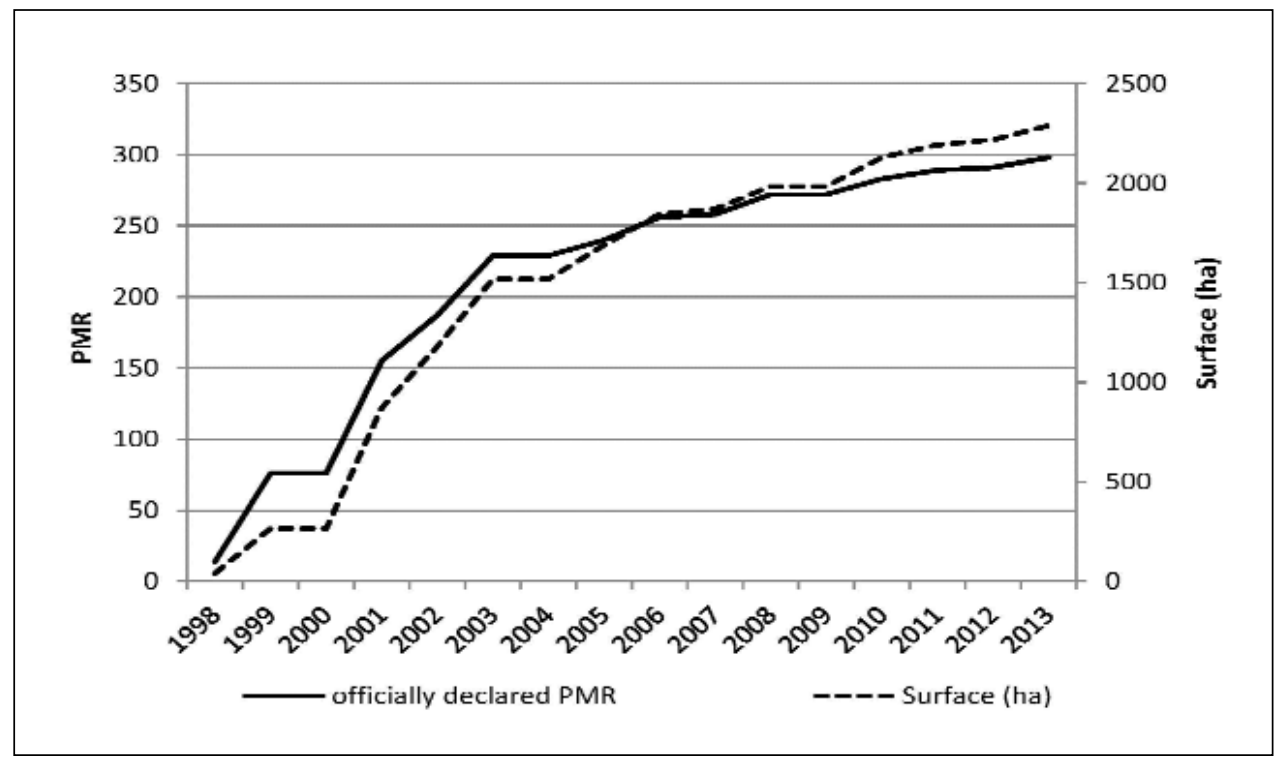

Fig. 2. Evolution of the number and surface of PMRs in the Valencian region. 
quantities for a number of particular purposes - educative, scientific or conservationist purposes - without prior administrative authorization.

PMRs have been selected as pilot projects or relevant examples in global reviews on in situ plant protection measures (Hamilton A. \& Hamilton C. 2006; Heywood 2004; Heywood \& Dulloo 2005; Moreno \& al. 2003) or as a recommended designation for national and regional legislations (Smart \& al. 2002). Some qualitative good external evaluations have been made on the concept and results (Akeroyd 1998; Raeymaekers 2000; Silva \& al. 2008) and they have been used as examples of good practices in plant conservation (Dulloo \& al. 2008; Silva \& al. 2009). However, an in depth analysis of their effectiveness regarding plant conservation is lacking. Thus, the aim of this study is twofold: first, to explore if the PMR network has incorporated the relevant plant species targeted for conservation in the Valencian region, and, second, to assess if the network affords a degree of passive protection that meets the conservation needs of the targeted species.

\section{Materials and methods}

In order to assess if the PMR network provides enough passive protection, merely as in situ protected conservation scheme, to rare, endemic or threatened plant species of the Valencian region, we have used floristic data compiled for PMR, updated August 2013. These data are also available from the Biodiversity Databank of the Valencian Region (BDB, http://bdb.cma.gva.es).

The classification of endemism proposed by Laguna (1998) has been used: Type A. Strict endemic species, only found in the Valencian region; Type B. Iberian or iberobalearic species with global distribution centred in Valencian region, as well as extremely rare endemic plants shared with neighbouring Spanish regions; Type C. Widely distributed Iberian endemics, mostly belonging to the group of Ibero-Levantine endemic plants, only to be found in the Eastern part of the Iberian peninsula. The concept of 'endemic' species for the groups B and C also includes Iberian and Iberian-Balearic species (Silene hifacensis, S. cambessedesii, Diplotaxis ibicensis, etc.). Iberian-Rifean species, shared with the Maghreb region in Northern Africa and often used by other Spanish authors (Blanca \& al. 2009), have not been considered here as endemic taxa.

Rarity is estimated according to Mateo \& Crespo (2009): very rare (RR), rare (R), moderately abundant (M), abundant (C) and very abundant (CC). Nomenclature also follows that used by the same authors. For endangered species, only taxa listed in the annexes of Decree 70/2009 have been taken into account.

In the discussion, a distinction between 'preventive' and 'effective/active' Natural Protected Areas has been made. The first type of areas comprises those which have no specific regulations to protect endangered plants and that merely confer an overall protection to the territory (i.e., Natura 2000 network). On the other hand, effective or active Natural Protected Areas are those sites where plants, and particularly threatened species, are often the target of specific conservation actions (i.e., National Parks, Nature Parks, Nature Reserves, Plant micro-reserves, etc.). 


\section{Results}

The updated list of Spanish endemics present in the Valencian Community includes 399 taxa of which $77 \%$ are found within the PMR network (Table 1. Endemicity). The results show a different degree of inclusion of endemic species within the PMR network with regard to the endemicity. In this respect, the highest percentage corresponds to the strict Valencian endemics (type A, 93\%), followed by those endemics shared with surrounding regions (type B, 88\%). Currently, only 5 strict Valencian endemic plants (Centaurea beltranii, Linaria orbensis, Limonium interjectum, Teucrium edetanum and Thymus richardii subsp. vigoi) have not yet been included in the network.

Regarding rarity, only native taxa have been taken into account. According to Mateo \& Crespo (2009), 1.746 Valencian plant species (60.3\% of the total flora) can be considered rare (R) or very rare (RR) plants. $48.7 \%$ of these species are included within the PMR network (Table 1, Rarity degree). This proportion is even lower $(38.7 \%)$ if only very rare species (RR) are considered.

The low success of the network regarding inclusion of rare species can be accounted for by two reasons:

a. Its main goal for a long period (1998-2008) was to incorporate populations of endemic species. Although a high proportion of rare plants in the Valencia region can be considered relict species (Laguna 1998) - with some of them being quite well represented in the PMR network (Serra \& al. 2004, 2007) - included within this group are a significant number of species that grow in nitrophilous and other widespread habitats, which were not targeted by the PMR network, due to their low level of naturalness (for instance, species linked to cereal fields), in the sense proposed by Machado (2004).

b. As established by their legal framework, PMR can only be designated by the regional Wildlife Service on public property areas or on those managed by public administrations. In fact, PMR cannot be designated against a landowner's will on his grounds (Laguna 2001). To this fact should be added that the rarest species grow in a very restricted range of sites within the Valencia region and that the proportion of lands under public management in natural areas is lower $(36 \%)$ than that under private management $(55.2 \%)$. Thus, the resulting probability of the PMR network including these species will be low.

An alternative method to measure the ability of PMR to incorporate populations of rare plant species is to compare the proportion of two plant groups - Rare (R+RR) vs. Abundant $(\mathrm{M}+\mathrm{C}+\mathrm{CC})-$ within and outside the network: In this case, the ratio is close to $60 / 40$ for the whole Valencian flora, while for the subset within PMR it goes down to 50/50.

Representativeness of threatened species within the PMR network is proportionally the lowest (Table 1, Protection categories), with 57\% of the protected plants being represented by one or more populations. This proportion is slightly higher for the Catalogued Taxa (63.0\%).

To explain these data, the same reasons as those put forward for the rare plants can be applied here, since most endangered Valencian plants are also some the rarest plants in the region (Aguilella \& al. 2010; Laguna 1998). 
Table 1. Representativeness of endemic, rare and protected plant species in Valencian Community and in the PMR network. Percentages are calculated by rows. * 6 species, probably extinct or dubiously present in Valencian Region, have been excluded from this evaluation.

\begin{tabular}{|c|c|c|c|c|}
\hline & & $\begin{array}{c}\text { Valencian Region } \\
\text { (Nr of taxa) }\end{array}$ & $\begin{array}{c}\text { PMR } \\
\text { (Nr of taxa) } \\
\end{array}$ & $\%$ \\
\hline \multirow{4}{*}{ 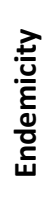 } & Type A & 70 & 65 & 92,9 \\
\hline & Type B & 93 & 82 & 88,2 \\
\hline & Type C & 236 & 161 & 68,2 \\
\hline & Total & 399 & 308 & 77,2 \\
\hline \multirow{8}{*}{ 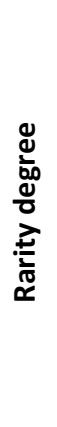 } & $\mathrm{RR}$ & 793 & 307 & 38,7 \\
\hline & $\mathrm{R}$ & 953 & 544 & 57,1 \\
\hline & $\mathbf{R}+\mathbf{R}$ & 1.746 & 851 & 48,7 \\
\hline & M & 714 & 524 & 73,4 \\
\hline & C & 305 & 263 & 86,2 \\
\hline & $\mathrm{CC}$ & 129 & 73 & 56,6 \\
\hline & $M+C+C C$ & 1.148 & 860 & 74,9 \\
\hline & Total & 2.894 & 1.711 & 59,1 \\
\hline \multirow{7}{*}{  } & Imperiled of Extinction & 40 & 23 & 57,5 \\
\hline & Vulnerable & 79 & 52 & 65,8 \\
\hline & $\begin{array}{l}\text { Catalogued species } \\
\text { (upper categories) }\end{array}$ & $119 *$ & 75 & 63,0 \\
\hline & $\begin{array}{l}\text { Protected but Non- } \\
\text { Catalogued }\end{array}$ & 109 & 43 & 39,5 \\
\hline & Guarded Species & 164 & 105 & 64,0 \\
\hline & Lower categories & 273 & 148 & 54,2 \\
\hline & Total & 392 & 224 & 57,1 \\
\hline
\end{tabular}




\section{Discussion and conclusions}

The starting point to evaluate protection of endangered endemic plant species in Spain (Mendoza-Fernández \& al. 2009) and elsewhere (Hernandez \& Gómez-Hinostrosa 2011; Bulut \& Yilmaz 2010) has been the networks of large protected areas. Their results cannot be easily compared with those presented here, as they are only referred to a network of small protected sites. The main conclusion drawn by these authors is the need to complement big networks with scattered small-sized reserves, as has already been made in the Valencian region. Previous studies have analyzed the contribution of small protected areas to the global protection of biodiversity (Falkner \& Stohlgren 1997), but starting from a different approach, and only attempting to establish how those small sites can complement the gaps of bigger networks. The authors' conclusion is in line with formerly cited works in the framework of the SLOSS debate, the need for complementary networks of large and small protected sites (Järvinen 1982).

The results of some large-scale analysis have linked rareness and endemicity (Domínguez \& al. 2003) and have used the endemicity as an indicator for conservation needs in Spain and the Iberian Peninsula (Domínguez \& al. 2000). However, the interpretation of their results has been often limited by the low availability of reliable data or by the small number of species involved in their analyses. In other cases, species richness has been used to test the effectiveness of protection measures (Araújo \& al. 2007; Lobo \& al. 2001), instead of the number of endangered species. The main conclusion drawn by most of these studies is the need to enlarge the networks of protected areas to reach enough representativeness for one or more of the significant groups of plant species (endemic, rare or threatened species) or for species richness as a whole (Castro $\&$ al. 1996). Unfortunately, currently available works on this topic often deal with a very restricted number of protected sites or refer to networks of preventive protected areas, such as Natura 2000. Often, this network only affords a preventive but not effective protection, since it lacks the regulatory framework needed to protect the most endangered species (Araújo \& al. 2007). However, some very recent works linking protected sites and needs of in situ protection for threatened species in Spain, like that of MuñozRodríguez \& al. (2013), have used the Natura 2000 network to test this effectiveness, instead of the more effectively protected sites, like networks of National and Natural Parks, Nature Reserves and other Natural Protected Areas.

Several works based on other approaches, like Important Plant Areas (IPAs), but using networks of actively protected sites, also show significant gaps regarding incorporation of relevant species and habitats. In this respect, Gil \& al. (2006) show that 39\% of the sites that deserve protection as IPAs remained outside the regional network of Natural Protected Areas in the Spanish Navarra region. Venter \& al. (2014) show that $17 \%$ of the threatened bird, mammals and amphibians species at a global level, are outside current protected areas worldwide, and that in situ protection for most of them could be efficiently provided by investing only 1,5 times more than the cheapest solution.

As a result of the lack of good analysis on networks of small protected sites focused on plant protection, a comparison with our results is not possible nowadays. Besides, no exact thresholds can be easily established to estimate the effectiveness of the PMR network as protection figure for rare, endemic or threatened plant species. Indeed, what percentage of species "incor- 
porated" to a network of small protected areas should be considered good regarding its effectiveness as a protection tool? If $50 \%$ of taxa included within the network were to be considered as a reasonable threshold, the Valencian PMR network would have achieved excellent results for the endemic taxa, which is quite good for the threatened taxa, but still not good enough, but close, for the rare species. On the contrary, if the level were to be raised say to $75 \%$, only endemic species would score in the current configuration of the network. Additionally, a crossanalysis with the coverage of in situ protection provided by the remainder effective protected areas of the Valencian region (Natural Parks, Nature Reserves and other kinds of active protected sites), should be made in the near future to complement our data.

\section{Acknowledgements}

The development of the Valencian PMR network has been made possible with the European Union's support through LIFE and EAFRD funds. The authors would like to acknowledge the collaboration of the plant officers working for the Valencian Wildlife Service (Servicio de Vida Silvestre, Generalitat Valenciana), for providing updated information on the plant species richness for each PMR. Additionally, we wish to thank Dr. V.I. Deltoro for polishing the English version.

\section{References}

Akeroyd, J. 1998: Micro-reserves 'capture' Valencia's rare plants. - Pl. Talk 14: 20-23, 33.

Aguilella, A., Fos, S. \& Laguna, E. (eds.) 2010: Catálogo Valenciano de Especies de Flora Amenazadas. - Valencia.

Anonymous 1994: Decreto 218/1994, de 17 de octubre, del Gobierno Valenciano, por el que se crea y regula la figura de protección denominada Microrreserva Vegetal. - Diari Oficial de la Generalitat Valenciana 2.379: 12.948-12.951.

Anonymous 2009: Decreto 70/2009, de 22 de mayo, del Consell, por el que se crea y regula el Catálogo Valenciano de Especies de Flora Amenazadas y se regulan medidas adicionales para su conservación. - Diari Oficial de la Comunitat Valenciana 6.021: 20.143-20.162.

Araújo, M., Lobo, J. M. \& Moreno, J. C. 2007: The effectiveness of Iberian protected areas in conserving terrestrial biodiversity. - Conserv. Biol. 21(6): 1423-1432. doi: 10.1111/j.15231739.2007.00827.x

Blanca, G., Cabezudo, B., Cueto, M., Fernández López, C. \& Morales Torres, C. 2009: Flora Vascular de Andalucía Oriental. - Sevilla.

Bulut, T. \& Yilmaz, H. 2010: The current situation of the threatened endemic flora in Turkey: Kemaliye (ErzIncan) case. - Pakistan J. Bot. 42(2): 711-719.

Castro, I., Moreno, J. C., Humphries, C. J. \& Williams, P. H. 1996: Strengthening the Natural and National Park system of Iberia to conserve vascular plants. - Bot. J. Linn. Soc. 121: 189-206.

Domínguez, F., Moreno, J. C. \& Sainz, H. 2003: Rarity and threat relationships in the conservation planning of Iberian flora. - Biodiv. Conserv. 12: 1861-1882.

—, Galicia, D., Moreno, L., Moreno, J.C. \& Sainz, H. 2000: Areas of high floristic endemism in Iberia and the Balearic Islands: an approach to biodiversity conservation using narrow endemics. - Belgian J. Entomol. 2: 171-185.

Dulloo, M.E., Labokas, J., Iriondo, J.M., Maxted, N., Lane, A., Laguna, E., Jarvis, A. \& Kell, S.P. 2008: Genetic Reserve location and design. - Pp. 23-64 in: Iriondo, J. M., Maxted, N. \& Dulloo, M. E. (eds.), Conserving Plant Genetic Diversity in Protected Areas. Population management of Crop Wild Relatives. - Wallingford. 
Falkner, M.B. \& Stohlgren, T.J. 1997: Evaluating the contribution of small national park areas to regional biodiversity. - Nat. Areas J. 17: 324-329.

Gil, T., Berasategi, A., Lorda, M. \& Peralta, J. 2006: Important Plant Areas in Navarra region (N Spain). Pp. 1-14 (PDF file in CD-Rom edition) in: Aguilella, A., Ibars, A. M., Laguna, E. \& Pérez Rocher, B. (eds.), Proceedings of the 4th European Conference on the Conservation of Wild Plants. - Valencia.

Hamilton, A. \& Hamilton, P. 2006: Plant Conservation: An ecosystem approach. - London.

Hernandez, H .M. \& Gómez-Hinostrosa, C. 2011: Areas of endemism of Cactaceae and the effectiveness of the protected area network in the Chihuahuan Desert. - Oryx 45(2): 191-200. doi: $10.1017 / \mathrm{S} 0030605310001079$

Heywood, V.H. 2004: Critical global review of existing guidelines and methodologies and other relevant literature on in situ conservation of target plant species and of current activities in this area being undertaken by national and international agencies. - Rome.

— \& Dulloo. M. E. 2005: In situ conservation of wild plant species. A critical global review of good practices. - Rome.

Järvinen, O. 1982: Conservation of endangered plant populations: single large reserves or several small reserves? - Oikos 38: 301-307.

Laguna, E. (ed.) 1998: Flora endémica, rara o amenazada de la Comunidad Valenciana. - Valencia.

- 2001: The micro-reserves as a tool for conservation of threatened plants in Europe. - Strasbourg.

—, Deltoro, V. I., Pérez-Botella, J., Pérez-Rovira, P., Serra, L., Olivares, A. \& Fabregat, C. 2004: The role of small reserves in plant conservation in a region of high diversity in eastern Spain. Biol. Conserv. 119(3): 421-426.

—, Ballester, G., Deltoro, V. I., Fabregat, C., Fos, S., Olivares, A., Oltra, J.E., Pérez Botella, J., Pérez Rovira, P. \& Serra, L. 2011: La red valenciana de microrreservas de flora: Síntesis de 20 años de experiencia. - Pp. 265-272 in: Giménez, P., Marco, J. A., Matarredona, E., Padilla, A. \& Sánchez, A. (eds.), Biogeografía. Una ciencia para la conservación del medio. - Alicante.

—, 一, - Fos, S., Carchano, R., Oltra, J. E., Pérez Botella, J. \& Pérez Rovira, P. 2013: A pioneer project: The Valencian Plant Micro-reserves network. - Pp. 13-23 in: Kadis, C., Thanos, C. \& Laguna, E. (eds.), Plant micro-reserves: From theory to practice. Experiences gained from EU LIFE and other related projects. - Athens.

Lobo, J.M., Castro, I. \& Moreno, J. C. 2001: Spatial and environmental determinants of vascular plant species richness distribution in the Iberian Peninsula and Balearic Islands. - Biol. J. Linn. Soc. 73: 233-253.

Machado, A. 2004: An index of naturalness. - J. Nat. Conserv. 12: 95-110.

Mateo, G. \& Crespo, M. B. 2009: Manual para la determinación de la flora valenciana, 4rt. ed. -Alicante.

Mendoza-Fernández, A., Martínez-Hernández, F., Garrido, J.A., Pérez-García, F.L., Medina, J.M., Peñas de Giles, J. \& Mota, J.F. 2009: Is the endangered flora of the Iberian southeast adequately protected? Gaps in the network of Protected Natural Areas of Andalusia (RENPA): the case of the province of Almeria. - Acta Bot. Gallica 156(4): 637-648. doi: 10.1080/12538078.2009.10516182

Moreno, J.C., Domínguez, F. \& Sainz, H. 2003: Recent progress in conservation of threatened Spanish vascular flora: a critical review. - Biol. Conserv. 113: 419-431.

Muñoz-Rodríguez, P., Draper, D., López-Huerta, R. \& Moreno, J. C. 2013: Conservación in situ de la flora vascular española amenazada. ¿Se alcanza el objetivo 7 de la Estrategia Global de Conservación Vegetal?. - Pp. 35 in: Sánchez Gómez, P. \& Torrente, P. (coords.), Libro de Resúmenes, $6^{\circ}$ Congreso de Biología de la Conservación de Plantas. - Murcia.

Raeymaekers, G. 2000: Plant conservation. In the beginning of a new era? - Natura 12(2000): 8-10 
Serra, L., Pérez-Rovira, P., Deltoro, V.I., Fabregat, C., Laguna, E. \& Pérez-Botella, J. 2004: Distribution, status and conservation of rare relict plant species in the Valencian Community.

- Bocconea 16(2): 857-863.

—, - Olivares, A., Laguna, E. \& Ballester, G. 2007: Proyecto LIFE "Gestión y valoración de 3 hábitats de alta montaña": Acciones sobre Taxus baccata. - Pp 119-126 in: Serra, L. (ed.), El Tejo en el Mediterráneo Occidental. - Alicante.

Servicio de Vida Silvestre. 2013: Informe técnico 08/2013: Valoración de la figura de microrreserva de flora. - Valencia. [http://www.citma.gva.es/documents/91061501/ 91067826/08_2013+Valoracion+de+la+figura+de+MRF/f63aa1f9-f8d5-47f7-ab81$855 \mathrm{dc} 18 \mathrm{c} 08 \mathrm{~b} 1$ ? version=1.0]

Silva, J., Toland, J., Jones, W., Elridge, J., Thorpe, E., Campbell, M. \& O'Hara, E. 2008: LIFE and endangered plants. Conserving Europe's threatened flora. - Bruxelles.

,,,---- , Hudson, T., Thorpe, E. \& O'Hara, E. 2009: Protecting Europe's Nature: Earning from LIFE Nature conservation best practices. - Bruxelles.

Smart, J., Imboden, Ch., Harper, M. \& Radford, E. (eds.) 2002: Saving the Plants of Europe. European Plant Conservation Strategy). - London.

Venter, V., Fuller, R.A., Segan, D.B., Carwardine, J, Brooks, T., Butchart, S.H.M., Di Marco, M., Iwamura, T., Joseph, L., O’Grady, D., Possingham H. P., Rondinin, C., Robert, J., Smith, R. J., Venter, M., James E. M. \& Watson, J.E.M. 2014: Targeting global protected area expansion for imperiled biodiversity. - PLOS Biol. 12(6): e1001891. doi:10.1371/journal.pbio.1001891

Addresses of the authors:

Simón Fos Martín ${ }^{1}$, Emilio Laguna Lumbreras² \& Juan Jiménez Pérez ${ }^{2}$,

${ }^{1}$ VAERSA, Conselleria d'Infraestructures, Territori i Medi Ambient, C./ Tres Forques, 98, 46018-Valencia, Spain. e-mail: flora_catalogada@gva.es

${ }^{2}$ Generalitat Valenciana, Conselleria d'Infraestructures, Territori i Medi Ambient, Dirección General de Medio Natural. Servicio de Vida Silvestre, Ciutat Adeministrativa, 9 d'Octubre, C./ Castán Tobeñas, 77, 46018-València, Spain. email: laguna_emi@gva.es, jimenez_juaper@gva.es. 